\title{
Research on the Construction of Ethical Competence Model of Corporate Top Manager
}

\author{
Chen Guo \\ Business School \\ Hu Bei University \\ Wuhan, China \\ guochen0714@126.com
}

\author{
Nianjiao Peng \\ ${ }^{\mathrm{a}}$ Business School \\ Hunan International Economics University \\ Changsha, China \\ ${ }^{\mathrm{b}}$ Business School \\ University of Edinburgh \\ Edinburgh, the United Kingdom \\ pengn@hieu.ed.cn
}

\author{
Lang $\mathrm{Wu}^{*}$ \\ College of Management \\ Shenzhen University \\ Shenzhen, China \\ wulang1016@126.com
}

\begin{abstract}
Corporate top manager plays an important role in the company and is responsible for solving ethical issues. This paper sorts out related theoretical researches on ethical competence or model. Through behavioral event interviews and questionnaire surveys, the ethical competence model for corporate top manager is constructed, which enriches the research objectives of the ethical competence model. It also provides theoretical guidance for companies in human resource management .
\end{abstract}

Keywords-Corporate top manager; Ethical competence; Ethical competence model

\section{INTRODUCTION}

In recent years, the level of Corporate Social Responsibility (CSR) which focus on the ethical responsibility has been low and is usually at an early stage in China. As Corporate Top Manager (CTM) plays an important role in the company, the level of their ethical competence determines, to a certain extent, the ability of company to solve CSR problems.

Ethical competence is a conscious decision and action within the scope of responsibility. It means that the object must carry out its own ethical principles [1]. So, it is of great significance to study the components of the Ethical Competence Model (ECM) of the CTM and to enhance their ethical competence. Based on the research of scholars at home and abroad, this paper selects CTM who come from local companies as research objects to explore the constituent factors of the ECM, and provides theoretical guidance for improving the ethical competence of CTM.

\section{DESIGN THE INDICATOR SYSTEM OF CTM ETHICAL COMPETENCE}

\section{A. Classification of Ethical Competence}

At present, the academic research on ethical competence mainly focuses on the education, medical, and public service industries, or from the perspective of the whole company. Based on the research results of ethical competence article about doctors [2] [3] [4], school leaders and teachers [5] [6], civil servants [7] [8] [9] [10] [11], the 14 indicators that may constitute the ethical competence model of CTM are summarized. The specific description is shown in Table I.

\section{B. Design and Implement the Behavioral Event Interview}

The Behavior Events Interview (BEI) is a method proposed by the American psychologist McClelland specifically for building a competence model [12]. According to the experience of domestic and foreign scholars in BEI, this paper selects three hard criterions, namely, the working years, the honor obtained, and the satisfaction of stakeholders, to distinguish excellent and ordinary CTM. With regard to the determination of the BEI sample size, most scholars currently believe that it is necessary to achieve more than 20 [13]. According to the criterions and related research, $23 \mathrm{CTM}$ are divided into excellent group (12 samples) and ordinary group (11 samples). The basic information of the interview sample is shown in Table II.

According to the description of the 23 CTM in the interview process, the ethical competencies with higher frequency are selected. In accordance with the three dimensions of ethical knowledge, ethical skills, and ethical attitudes or values, the paper initially screens the CTM ethical competence indicators. The specific description is shown in Table III 
TABLE I. CTM ETHICAL COMPETENCE ALternatives

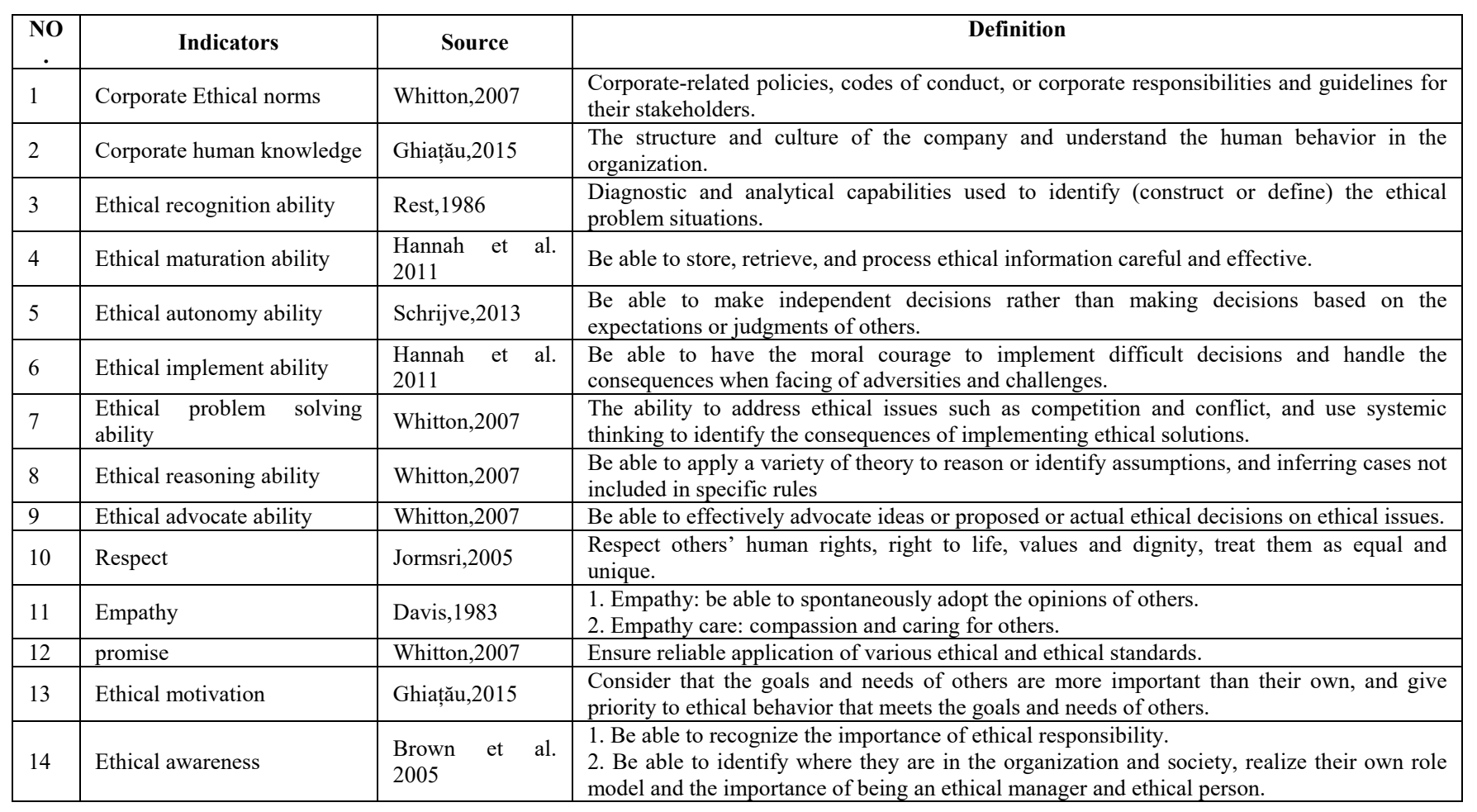

TABLE II. BASIC INFORMATION OF INTERVIEW SAMPL

\begin{tabular}{|c|c|c|c|}
\hline $\begin{array}{c}\text { Inde } \\
\quad x\end{array}$ & classification & $\begin{array}{l}\text { NO. (total } \\
23 \text { ) }\end{array}$ & $\begin{array}{c}\text { perce } \\
\text { ntage } \\
(\% \\
)\end{array}$ \\
\hline \multirow{2}{*}{$\begin{array}{l}\text { Gend } \\
\text { er }\end{array}$} & Male & 18 & 78 \\
\hline & Female & 5 & 22 \\
\hline \multirow{3}{*}{ Age } & $35 \sim 45$ & 10 & 43 \\
\hline & $45 \sim 55$ & 8 & 35 \\
\hline & Above 55 & 5 & 22 \\
\hline \multirow{2}{*}{$\begin{array}{l}\text { Positi } \\
\text { on }\end{array}$} & $\begin{array}{l}\text { Middle } \\
\text { manager }\end{array}$ & 15 & 65 \\
\hline & $\begin{array}{l}\text { Senior } \\
\text { manager }\end{array}$ & 8 & 35 \\
\hline \multirow{2}{*}{$\begin{array}{l}\text { Work } \\
\text { ing } \\
\text { years }\end{array}$} & $5 \sim 10$ years & 14 & 61 \\
\hline & $\begin{array}{ll}\begin{array}{l}\text { Above } \\
\text { years }\end{array} & 10 \\
\end{array}$ & 9 & 39 \\
\hline \multirow{2}{*}{$\begin{array}{l}\text { Busi } \\
\text { ness } \\
\text { attrib } \\
\text { utes }\end{array}$} & state-owned & 7 & 30 \\
\hline & private & 16 & 70 \\
\hline \multirow{3}{*}{$\begin{array}{l}\text { Busi } \\
\text { ness } \\
\text { scale }\end{array}$} & $100 \sim 500$ & 8 & 35 \\
\hline & $500 \sim 1000$ & 10 & 43 \\
\hline & Above 1000 & 5 & 22 \\
\hline
\end{tabular}

Using SPSS19.0 to analyze the duration of interview, the total frequency of competence, the average number of competence grades, and the coding reliability, it is proved that the difference in the competence of outstanding CTM and ordinary ones are not related to the interview duration and total frequency of competence, but related to the average of each competence level.
TABLE III. THE PRELIMINARY SUMMARY OF CTM ETHICAL

\begin{tabular}{|l|l|}
\hline \multicolumn{1}{|c|}{ First-level indicators } & \multicolumn{1}{c|}{ Secondary indicators } \\
\hline \multirow{4}{*}{ Ethical knowledge } & Corporate ethical norms \\
\cline { 2 - 3 } & Ethical education level \\
\cline { 2 - 2 } & Corporate human knowledge \\
\hline \multirow{5}{*}{ Ethical skills } & Ethical recognition ability \\
\cline { 2 - 2 } & Ethical maturation ability \\
\cline { 2 - 2 } & Ethical autonomy ability \\
\cline { 2 - 2 } & Ethical implement ability \\
\cline { 2 - 2 } & Ethical problem solving ability \\
\cline { 2 - 2 } & Ethical advocate ability \\
\hline \multirow{5}{*}{ Ethical attitudes or values } & Respect \\
\cline { 2 - 2 } & Empathy \\
\cline { 2 - 2 } & Ethical motivation \\
\cline { 2 - 2 } & Ethical awareness \\
\cline { 2 - 2 } & promise \\
\hline
\end{tabular}

Based on the above preliminary summary list of CTM ethical competence, the questionnaire mainly includes four parts: demographic variables, ethical knowledge, ethical skills, and ethical attitudes or values. For the measurement of variables, this paper adopts the Likert 5-point scale. The respondent scores each question according to his own opinion. 1 represents the lowest score, 5 represents the highest score, and from 1 to 5 indicates that it is completely absent agree,disagree, neutral, agree and fully agree.

\section{Questionnaire Design}

In general, BEI can be used as a routine method for building competence model. However, its deficiency lies in its small 
sample of interviewees (23 BEI samples in this paper). In order to build a more accurate ethical competence model of CTM, the paper will further explore more precise models based on the above-mentioned conclusions of BEI.

\section{Questionnaire Implementation}

The questionnaires are distributed online and offline. The online questionnaires distributed by social medium. The respondents both online and offline are CTM of MBA students recommended by mentors and alumnus.

1) Pre-research: This paper conducted a pre-research to ensure the validity of the questionnaire. Pre-research issued 58 questionnaires, and recovered 51 valid questionnaires. Reliability, validity analysis and factor analysis are performed on 51 recovered questionnaires. Those items that caused Cronbach's Alpha coefficient to increase significantly or those whose factor load is less than 0.5 are excluded. After preresearch and deleting the items that do not meet the requirements, a questionnaire containing 12 ethical competences is finally formed, as shown in Table IV .

2) Formal research: A total of 387 questionnaires are distributed, 213 offline, 174 online, and a total of 321 returned. Eliminate 14 invalid questionnaires, the valid questionnaires are 307 , the effective rate is $76.8 \%$. The basic information of the respondents is shown in Table V.

a) Reliability analysis: In order to ensure the rationality and validity of subsequent data analysis, this paper uses Cronbach's Alpha coefficient and the composite reliability (CR) of latent variables to verify the consistent reliability within the ethical competences. Among them, if the Cronbach's Alpha coefficient and the $\mathrm{CR}$ value of each index are higher, the higher reliability of the measured index. According to the study of foreign scholars, Cronbach's Alpha coefficient is greater than 0.7 , indicating that the measurement of indicators has good reliability [14]. The reliability and combined reliability of the indexes measured in this paper are greater than 0.7 , indicating that the internal consistency of the scale is good, as shown in TableVI. Therefore, through the above reliability analysis, the entire index measurement system is reliable and stable.

b) Validity analysis: Validity refers to the validity of the experiment, that is, the experimental score can show the level of the psychological characteristic of measured variable, or the degree to which the measurement results reach the purpose of the experiment. Validity consists of content validity and construct validity.

Content validity refers to the appropriateness and consistency of the goals and the content of the measurement. The indexes adopted in this paper are verified by domestic and foreign scholars through empirical research. It is considered that the scale of this paper has a good content validity.
TABLE IV. MEASURE ITEMS In Formal ScAleS

\begin{tabular}{|l|l|}
\hline \multicolumn{1}{|c|}{ Factors } & \multicolumn{1}{c|}{ Measure items } \\
\hline Demographic variables & $\begin{array}{l}\text { Gender, Age, Working years, Size of company, } \\
\text { Business attributes, Industry }\end{array}$ \\
\hline Ethical knowledge & $\begin{array}{l}\text { Corporate ethical norms, Ethical recognition, } \\
\text { Ethical awareness }\end{array}$ \\
\hline Ethical skills & $\begin{array}{l}\text { Ethical maturation ability, Ethical autonomy } \\
\text { ability, Ethical implement ability, Ethical problem } \\
\text { solving ability, Ethical advocate ability }\end{array}$ \\
\hline Ethical attitudes or values & Respect, Empathy, Ethical motivation, Promise \\
\hline
\end{tabular}

TABLE V. THE BASIC INFORMATION OF THE RESPONDENTS

\begin{tabular}{|c|c|c|c|}
\hline Index & classification & $\begin{array}{c}\text { NO.(total } \\
\mathbf{3 0 7} \text { ) }\end{array}$ & $\begin{array}{c}\text { Percentage( } \\
\%)\end{array}$ \\
\hline \multirow{2}{*}{ Gender } & Male & 261 & 85 \\
\hline & Female & 46 & 15 \\
\hline \multirow{3}{*}{ Age } & $35 \sim 45$ & 86 & 28 \\
\hline & $45 \sim 55$ & 164 & 53 \\
\hline & Above 55 & 57 & 19 \\
\hline \multirow{2}{*}{$\begin{array}{l}\text { Working } \\
\text { years }\end{array}$} & $5 \sim 10$ years & 185 & 60 \\
\hline & Above 10 years & 122 & 40 \\
\hline \multirow{3}{*}{$\begin{array}{l}\text { Business } \\
\text { scale }\end{array}$} & $100 \sim 500$ & 22 & 22 \\
\hline & $500 \sim 1000$ & 58 & 58 \\
\hline & Above 1000 & 20 & 20 \\
\hline \multirow{3}{*}{$\begin{array}{l}\text { Business } \\
\text { attributes }\end{array}$} & State-owned & 95 & 30.9 \\
\hline & Private & 187 & 60.9 \\
\hline & Foreign & 25 & 8.2 \\
\hline \multirow{6}{*}{ Industry } & $\begin{array}{l}\text { Automotive } \\
\text { Manufacturing }\end{array}$ & 56 & 18.2 \\
\hline & $\begin{array}{l}\text { Electric energy } \\
\text { industry }\end{array}$ & 28 & 9.1 \\
\hline & Service industry & 137 & 44.6 \\
\hline & $\begin{array}{l}\text { Information and } \\
\text { communication } \\
\text { industry }\end{array}$ & 30 & 9.8 \\
\hline & Construction industry & 25 & 8.2 \\
\hline & other & 31 & 10.1 \\
\hline
\end{tabular}

TABLE VI. RELIABILITy ANALYSIS RESUlts of ETHICAL COMPETENCE

\begin{tabular}{|l|l|l|}
\hline \multicolumn{1}{|c|}{ First-level indicators } & \multicolumn{2}{c|}{ Cronbach's Alpha } \\
\cline { 1 - 2 } Ethical knowledge & 0.902 & \multirow{2}{*}{0.891} \\
\cline { 1 - 2 } Ethical skills & 0.837 & \\
\cline { 1 - 2 } Ethical attitudes or values & 0.793 & \\
\hline
\end{tabular}

Structural validity refers to the level of the internal structure of the viewpoints or propositions, including the validity of convergence and the validity of discriminant. Convergence validity refers to the degree of correlation between the scale and other indexes of the same constituent. The normalized factor loads for all indexes are greater than 0.7 , and the average extracted variance (AVE) is greater than 0.5 , indicating that the scale has a good convergence validity, as shown in Table VII; Discriminant validity refers to the extent to which one index is independent of other indexes. The discriminant validity of this scale is tested by factor analysis. The results of factor analysis in the factor analysis section of this paper show that the scale has good discriminant validity. 
3) Factor analysis: This article uses SPSS19.0 to do factor analysis. Factor analysis was used to analyze the principal components of the 12 ethical competencies. The KMO value was 0.743 . Bartlett's sphericity test has a significance of 0.000 , indicating that it is suitable for factor analysis. The analysis results are shown in Table VIII and Table IX.

In order to obtain an ethical factor structure, this paper has three criteria for factor selection: first, the load of the index on the factor is greater than or equal to 0.5 ; second, there is a low cross-load between the indexes; thirdly, the intrinsic meaning of the index must be consistent. Only those indexes that meet the above three criteria can be retained. In the process of factor analysis, the principal component analysis was performed using the largest variance method with an eigenvalue greater than 1 , and finally three principal components were extracted. The cumulative contribution rate reached $78.95 \%$, which could well reflect the information contained in the 12 indicators. The results of factor analysis are shown in Table X. Only load factors greater than 0.5 are shown in the table. Load factors less than 0.5 are not shown. Combining the existing literature, this paper sorts out the results of the factor analysis, as shown in Table XI.

TABLE VII. VALIDITy ANALYSIS Results of Ethical COMPETENCE

\begin{tabular}{|c|c|c|c|}
\hline Index & $\begin{array}{c}\text { Standard } \\
\text { factor loading }\end{array}$ & AVE & $\mathbf{C R}$ \\
\hline Corporate ethical norms & 0.949 & \multirow{3}{*}{0.743} & \multirow{3}{*}{0.902} \\
\hline Ethical recognition & 0.820 & & \\
\hline Ethical awareness & 0.835 & & \\
\hline Ethical maturation ability & 0.831 & \multirow{5}{*}{0.711} & \multirow{5}{*}{0.919} \\
\hline Ethical autonomy ability & 0.813 & & \\
\hline Ethical implement ability & 0.854 & & \\
\hline Ethical problem solving ability & 0.810 & & \\
\hline Ethical advocate ability & 0.873 & & \\
\hline Respect & 0.864 & \multirow{4}{*}{0.719} & \multirow{4}{*}{0.912} \\
\hline Empathy & 0.860 & & \\
\hline Ethical motivation & 0.822 & & \\
\hline Promise & 0.845 & & \\
\hline
\end{tabular}

TABLE VIII. THE DESCRIPTIVE STATISTICS OF CTM ETHICAL COMPETENCE INDEX

\begin{tabular}{|l|c|l|l|}
\hline \multicolumn{1}{|c|}{ Index } & $\begin{array}{c}\text { Sampl } \\
\text { e }\end{array}$ & Mean & \multicolumn{1}{|c|}{$\begin{array}{c}\text { Standard } \\
\text { deviation }\end{array}$} \\
\hline Corporate ethical norms & 307 & 3.077 & 0.498 \\
\hline Ethical recognition & 307 & 3.347 & 0.353 \\
\hline Ethical awareness & 307 & 3.345 & 0.307 \\
\hline Ethical maturation ability & 307 & 2.880 & 0.318 \\
\hline
\end{tabular}

\begin{tabular}{|l|l|l|l|}
\hline \multicolumn{1}{|c|}{ Index } & $\begin{array}{c}\text { Sampl } \\
\mathbf{e}\end{array}$ & Mean & \multicolumn{1}{|c|}{$\begin{array}{c}\text { Standard } \\
\text { deviation }\end{array}$} \\
\hline Ethical autonomy ability & 307 & 3.500 & 0.759 \\
\hline Ethical implement ability & 307 & 3.311 & 0.249 \\
\hline Ethical problem solving ability & 307 & 3.451 & 0.385 \\
\hline Ethical advocate ability & 307 & 3.302 & 0.520 \\
\hline Respect & 307 & 3.372 & 0.330 \\
\hline Empathy & 307 & 2.813 & 0.693 \\
\hline Ethical motivation & 307 & 2.918 & 0.264 \\
\hline Promise & 307 & 3.175 & 0.373 \\
\hline
\end{tabular}

TABLE IX. THE KMO AND BARTLETT BALL TEST

\begin{tabular}{|l|l|l|}
\hline \multicolumn{2}{|c|}{ KMO Test } & \multicolumn{1}{c|}{0.743} \\
\hline \multirow{3}{*}{$\begin{array}{l}\text { Bartlett's sphericity } \\
\text { test }\end{array}$} & Approximate Chi-square & 2215.192 \\
\cline { 3 - 4 } & Degree of freedom & 253 \\
\cline { 2 - 3 } & Significant & 0.000 \\
\hline
\end{tabular}

TABLE X. ROTATED FACTOR LOADING MATRIX

\begin{tabular}{|l|l|c|c|}
\hline \multicolumn{1}{|c|}{ Index } & \multicolumn{3}{c|}{ Component } \\
\hline & $\mathbf{1}$ & $\mathbf{2}$ & $\mathbf{3}$ \\
\hline Corporate ethical norms & & 0.945 & \\
\hline Ethical recognition & & 0.770 & \\
\hline Ethical maturation ability & 0.664 & & \\
\hline Ethical autonomy ability & 0.910 & & \\
\hline Ethical implement ability & 0.650 & & \\
\hline Ethical problem solving ability & 0.711 & & \\
\hline Ethical advocate ability & 0.877 & & \\
\hline Respect & & & 0.789 \\
\hline Empathy & & & 0.670 \\
\hline Ethical motivation & & & 0.877 \\
\hline Ethical awareness & & 0.837 & \\
\hline Promise & & & 0.720 \\
\hline
\end{tabular}

a. Extraction method: main ingredient. Rotary method: With Kaiser normalized orthogonal rotation method. The rotation converges after 6 iterations.

TABLE XI. The Factor NAme of Ethical Competence Model

\begin{tabular}{|c|c|c|c|c|}
\hline $\begin{array}{c}\text { Facto } \\
\mathbf{r}\end{array}$ & Index & $\begin{array}{l}\text { Factor } \\
\text { loading }\end{array}$ & $\begin{array}{c}\text { Eigenvalue } \\
\mathrm{s}\end{array}$ & $\begin{array}{c}\text { CVC } \\
\text { R }\end{array}$ \\
\hline \multirow{3}{*}{$\begin{array}{l}\text { Ethica } \\
1 \\
\text { knowl } \\
\text { edge }\end{array}$} & Corporate ethical norms & 0.945 & \multirow{3}{*}{1.590} & \multirow{3}{*}{$\begin{array}{l}12.27 \\
0\end{array}$} \\
\hline & Ethical recognition & 0.770 & & \\
\hline & Ethical awareness & 0.837 & & \\
\hline \multirow{5}{*}{$\begin{array}{l}\text { Ethica } \\
1 \text { skills }\end{array}$} & Ethical maturity ability & 0.664 & \multirow{5}{*}{6.570} & \multirow{5}{*}{$\begin{array}{l}67.99 \\
5\end{array}$} \\
\hline & Ethical autonomy ability & 0.910 & & \\
\hline & Ethical implement ability & 0.650 & & \\
\hline & $\begin{array}{l}\text { Ethical problem solving } \\
\text { ability }\end{array}$ & 0.711 & & \\
\hline & Ethical advocate ability & 0.877 & & \\
\hline \multirow{4}{*}{$\begin{array}{l}\text { Ethica } \\
1 \\
\text { attitud } \\
\text { es or } \\
\text { values }\end{array}$} & Respect & 0.789 & \multirow{4}{*}{1.310} & \multirow{4}{*}{$\begin{array}{l}78.95 \\
0\end{array}$} \\
\hline & Empathy & 0.670 & & \\
\hline & Ethical motivation & 0.877 & & \\
\hline & Promise & 0.720 & & \\
\hline
\end{tabular}




\section{CONCLUSION}

The research on components of the ethical competence model of CTM is very important, through the statistical method, this paper finally construct the CTM ethical competence model. There are two limitations in this paper, first, at the time of the interview, most CTM are not very clear about what ethical issues are, and are easily confused with economic and legal issues, which made the interview results have a certain impact; Second, this paper does not give examples to support the model, it is difficult, to a certain extent, to verify the practicality of ethical competence model. In the future, it is necessary to clearly define concepts and improve the effectiveness of interviews. Meanwhile, the model should be applied to the company. They can construct a measurement process to evaluate the ethical competence of CTM, and apply the assessment results to human resource management.

\section{ACKNOWLEDGMENT}

This work was partially supported by the China Postdoctoral Science Foundation (2016M602528), the Natural Science Foundation of Guangdong Province (2018A030310567).

\section{REFERENCES}

[1] R. Pohling, D. Bzdok, M. Eigenstetter, S. Stumpf, and A. Strobel, "What is Ethical Competence? The Role of Empathy, Personal Values, and the Five-Factor Model of Personality in Ethical Decision-Making," Journal of Business Ethics, vol. 137(3), pp. 449-474, 2016

[2] P. Jormsri, W. Kunaviktikul , S. Ketefian , and A. Chaowalit, "Moral competence in nursing practice," Nursing Ethics, vol. 12(6), pp. 582-94, 2005 .
[3] S. Eriksson, G. Helgesson, and A.T. Höglund, "Being, Doing, and Knowing: Developing Ethical Competence in Health Care," Journal of Academic Ethics, vol. 5(2), pp. 207-216, 2007.

[4] P. Tarja , L. Helena , and K. Jouko, "Supporting ethical competence of nurses during recruitment and performance reviews - the role of the nurse leader," Journal of Nursing Management, vol. 22(6), pp. 792-802, 2014.

[5] R.M. Ghiațău, "Ethical Competence for Teachers: A Possible Model," Symposion 2, vol. 2015(3), pp. 387-403.

[6] S.T. Hannah , B.J. Avolio, and D.R. May, "Moral maturation and moral conation: A capacity approach to explaining moral thought and action," Academy of Management Review, vol. 36(4), pp. 663-685, 2011.

[7] H. Whitton, "Developing the 'Ethical Competence' of Public Officials-a Capacity-building Approach,” ActaCrystallographica, vol. 63(8): m2114$\mathrm{m} 2114.2007$

[8] A.D. Schrijver and J. Maesschalck, A new definition and conceptualization of ethical competence// Achieving ethical competence for public service leadership, 2013, pp. 29-51.

[9] M.H. Davis, "Measuring individual differences in empathy: Evidence for a multidimensional approach," Journal of Personality \& Social Psychology, vol. 44(1), pp. 113-126, 1983

[10] M. E. Brown, L.K. Treviño, and D.A. Harrison, "Ethical leadership: A social learning perspective for construct development and testing," Organizational Behavior \& Human Decision Processes, vol. 97(2), pp. $117-134,2005$

[11] J.R. Rest, "Moral development: advances in research and theory," Advances in Solar Energy Technology, vol. 33, pp. 489-496. 1986.

[12] D.C. McClelland, "Testing for competence rather than for "intelligence"," American Psychologist, pp. 281, 1973.

[13] S. Kurian, N. Ribeiro, and D.R. Gomes, "Relevance of Behavioral Event Interview (BEI) in Selection Processes: A Corporate Sector Study," Iup Journal of Organizational Behavior, vol. 15, 2016.

[14] J.F. Hair, R.E. Anderson , R.L. Tatham, and W.C. Black, Multivariate Data Analysis, 5th Ed., New Jersey:Prentice Hall, 1998. 